\title{
Preliminary Results on the Incidence of Bacterial Disease Associated Symptoms on Sour Cherry (Prunus cerasus) Trees in Northern Romania
}

\author{
Smaranda-Doina ROȘU-MAREȘ*
}

Fruit Research and Development Station Bistrița, Romania

*Corresponding author: Smaranda-Doina ROȘU-MAREȘ e-mail: smaranda.boila@usamvcluj.ro

\section{SHORT COMMUNICATION}

\begin{abstract}
Bacterial diseases induce various symptoms on all fruit tree species cultivated in Bistrita area, north Transylvania, Romania. The preliminary results showed a very high incidence of bacterial associated symptoms in this sour cherry plot, only $1.14 \%$ of the trees was without any symptoms, and suggest a rapid evolution of the attack on leafs and young branches. In the future we will continue this study with laboratory tests in an attempt to determine the etiological agent causing the bacterial diseases in this orchard.
\end{abstract}

Keywords: blossom blight; canker; Pseudomonas syringae pathovars; sour cherry.

Received: 15 September 2020 Accepted: 7 December 2020 Published: 14 May 2021

DOI:

15835/buasvmen-hort:2020.0048

2021 Authors. The papers published in this journal are licensed under the Creative Commons Attribution-NonCommercialNoDerivatives 4.0 International License

\section{INTRODUCTION}

Bacterial diseases produce various symptoms on all fruit tree species cultivated in Bistrita area, north Transilvania, Romania. The severity of the symptoms differs between different species of trees, varieties, age of the three and affected organs. As studies show, each year yield losses due to diseases, all around the world, rise up to $20-40 \%$ of the production of fruits (Savary et al., 2012).

Taking into consideration the fact that symptoms of bacterial diseases have been observed in most of the stone fruit orchards in the area, in both treated and untreated plots we consider important to investigate which organs and which period in tree's life is more susceptible to be affected by bacterial diseases, in our area of interest. Another important aspect is to study the way that the disease symptoms progress throughout the summer.

Studies conducted on stone fruits orchards showed that there are more than one bacterial species or pathovars present where bacterial diseases occur. Where there is evidence that Pseudomonas syringae occurs, there are probably present both of its pathovars: Pseudomonas syringae pv. syringae and Pseudomonas syringae pv. morsprunorum in various proportions (Akkopru, 2016). The data collected in this study will represent the base for further determinations of the bacterial pathogens that affect the sour cherry orchards as well as other stone fruits cultivated in the north region of Romania. 


\section{MATERIALS AND METHODS}

The study was carried out in a 25 year plot of sour cherry (Prunus cerasus) property of Fruit Research and Development Station Bistrița (FRDSB), on three cultivars: 'Meteor', 'Crisane' and 'Engleze timpurii'. The trees were evaluated and noted for the symptoms usually associated with bacterial diseases (Iliescu and Severin, 2006) caused by Pseudomonas syringae pv syringae (Pss) and Pseudomonas syringae pv morsprunorum (Psm) races 1 and 2 (Kaluzna, 2016): cankers and lesions on the trunk and branches, dead buds with limited progression on the branch, blossoms blight with limited progression on the branch (Figure 1), gummosis, leaf spots and yellow leafs, dead branches on two periods of time in the summer of 2020 and for fruit spots were possible.



Figure 1. Blighted blossoms and lesions on a branch of 'Meteor' variety 15.07.2020

Observations were made on the same trees and no chemical treatments were applied on the time span between the evaluations from 14.07.2020 to 14.08.2020. Due to a cold period in the spring at blooming time of the cultivar 'Engleze timpurii' all flowers freezed and therefore we could evaluate the frequency of the spots only on fruits on the other two cultivars.

The Brown rot fungal disease caused by the fungus of the Monilinia genus also induce some of the symptoms mentioned above. Blossom blight, gummosis, lesions on the branches are often the effect of a fungal infection too. But there are certain symptoms like cankers on old branches and the bacterial spots on fruits and leaves that are different from the ones caused by Monilinia spp. The data collected in this preliminary study are only by visual inspection and the differentiation between the two groups of pathogens is difficult.

\section{RESULTS AND DISCUSSIONS}

The preliminary results showed a very high incidence of bacterial associated symptoms in this sour cherry plot, only $1.14 \%$ of the trees was without any symptoms at the end of the summer and suggest a rapid evolution of the attack on leafs and young branches. The percentage of the overall affected trees is high in the first round of observations and increases even more. The frequency of trees with leaf perforations has rose from $30 \%$ to $100 \%$ on Meteor and on all varieties from $12.5 \%$ to $71.59 \%$ (Figure 2).



Figure 2. Evolution of symptoms on Prunus cerasus trees in the 2020 summer 
Differences between the data collected in the two rounds of observation were statistically analysed using One way Anova Test and for three of the symptoms recorded the frequencies were significantly higher on 30.08 .2020 (Table 1).

Table 1. Significance of the differences between the frequency of the bacterial symptoms on 15.07.2020 and 30.08.2020, on Prunus cerasus trees

\begin{tabular}{lccc}
\hline \multicolumn{1}{c}{ Sympthom } & F calculated value & $\begin{array}{c}\text { F critical } \\
\text { value }\end{array}$ & Significance \\
\hline Perforated leafs & 13,011130 & 5,987378 & Yes \\
\hline Gummosis on all three varieties & 4,686873 & 5,987378 & No \\
\hline Cankers-lesions & 8,864522 & 5,987378 & Yes \\
\hline Dead branches on all three varieties & 3,330535 & 5,987378 & No \\
\hline $\begin{array}{l}\text { Dead branches on 'Crisane and 'Engleze } \\
\text { timpurii' }\end{array}$ & 21,477180 & 7,708647 & Yes \\
\hline
\end{tabular}

There were differences in the way that the symptoms progressed throughout the summer, between the three cultivars. On 'Crisane' cultivar the percentage of the trees with dead branches has grown from $33.33 \%$ to $67.74 \%$ by the end of the summer. On 'Engleze timpurii' the percentage has risen from $29.63 \%$ to $59.60 \%$. In the same time the percentage of the trees with dead branches, on 'Meteor' was the same at the end of the summer as it was in June.

Many of the blossom blight affected small branches died throughout the summer. Taking into consideration that some of the blighted blossoms had gummosis and remained attached on the branches while others didn't as well as the meteorological conditions in the spring of 2020 the study will be continued with laboratory tests to determine the nature of blight (fungal or bacterial). Overall the evaluated symptoms on leafs and branches increased their frequency by the end of the summer.

Also, bacterial spots were present on the fruits on the two varieties that were not affected by the spring freezing. The percentage of fruits that had bacterial spots was $10 \%$ on the 'Crisane' cultivar and $19.35 \%$ on the 'Meteor' cultivar at harvesting maturity.

\section{CONCLUSIONS}

Considering that all of the aerial organs of the trees were affected by the symptoms that are usually associated with bacterial diseases, we find important to further study the incidence and determine the causal agent, in order to better control the effects on the trees and on the sour cherry fruit production.

Author Contributions: S.R-M. collected, analyzed data and wrote the paper.

Funding Source: This research was funded by Romanian Academy for Agriculture and Forestry through project no. $1748 / 2019$.

Acknowledgments: Many thanks to my doctoral adviser professor Puia Carmen for her valuable guidance.

Conflicts of Interest: There are no conflicts of interest.

\section{REFERENCES}

1. Akkopru A (2016). Determination of bacterial disease on stone fruits grown in Lake Van Basin, East Anatolia of Turkey. Acta Horticuture. 1149: 15-19.

2. Iliescu CH, Severin V (2006). Bolile bacteriene ale plantelor. Bucharest: Geea.

3. Kaluzna M, Willems A, Pothier JF, Ruinelli M, Sobiczewski P, Pulawska J (2016). Characterization and genetic diversity of causal agent of stone fruit canker Pseudomonas cerasi, a new pathogen of cherry. Acta Horticulture. 1149: 9-13.

4. Savary S, Ficke A, Aubertot J, Hollier C (2012). Crop losses due to disease and their implications for global food production losses and food security. Food Secur. 4: 519-537 